\title{
Effect of gluten-free diet on splenic hypofunction of adult coeliac disease
}

\author{
G R CORAZZA, ${ }^{*}$ M FRISONI, D VAIRA, AND G GASBARRINI
}

From the III Department of Medical Pathology, Policlinico S. Orsola, Bologna University, Bologna, Italy

SUMmaRY Splenic function has been serially measured by counting pitted red cells in 15 coeliac patients, before and during a gluten-free diet. The basal percentage values of pitted cells decreased significantly during treatment but no correlation was observed between the duration of the gluten-free diet and the percentage of recovery of splenic function over basal values. Out of six coeliacs with pitted cell values consistent with splenic hypofunction, three showed a total recovery after gluten withdrawal. Our data suggest that, contrary to recent reports, hyposplenism in adult coeliac disease is improved by a gluten-free diet, and that environmental factors may be important in determining and maintaining this complication.

Although the mechanisms underlying the hyposplenism which can occur in adult coeliac disease are still unknown, several features of this complication have been recently clarified. Hyposplenism can complicate adult coeliac disease in $30-50 \%$ of the cases $^{1-3}$ and it is not associated with a more generalised reticuloendothelial dysfunction. ${ }^{+}$Its occurrence seems to be connected with an impairment of the immune response ${ }^{56}$ and a raised incidence of autoimmunity and malignancy. ${ }^{7}$ It is. therefore. important to evaluate whether a strict gluten-free diet can improve. and in some cases reverse. impaired splenic function, or whether, as recently suggested, ${ }^{8}$ the hyposplenism in adult coeliac disease is a condition unaffected by treatment.

In this study we have assessed splenic function in adult coeliac disease before and during a gluten-free diet, using a new non-invasive test already applied to the study of splenic hypofunction in treated coeliacs. $^{3}$

\section{Methods}

PATIENTS

Splenic function was assessed in 15 coeliac patients (mean age 43.3 years, range 24-61 years) before and during different periods (mean duration 6.1 months, range 3-12 months) of a gluten-free diet. The

* Address for correspondence: Dr G R Corazza. III Patologia Medica. Policlinico S. Orsola. Via Massarenti 9.40100. Bologna. Italy.

Received for publication 17 May 1982 diagnosis of adult coeliac disease was based on an abnormal jejunal mucosa (subtotal or severe partial villous atrophy) with histological evidence of improvement on gluten withdrawal. In all patients none of the conditions associated with splenic hypofunction or severe anaemia with reticulocytosis was present.

SPLENIC FUNCTION MEASUREMENT

Splenic function was measured by counting the percentage of red cells bearing membrane abnormalities visible under interference microscopy as 'pits' (pitted cells). Briefly, a drop of fresh venous blood was mixed with $0.5 \mathrm{ml} 3 \%$ buffered glutaraldehyde solution, $\mathrm{pH} 7 \cdot 4$. Two thousand red cells were examined in a wet preparation (magnification $\times 1000$ ) with a direct interference contrast microscope (Leitz Dialux 20, equipped with Nomarski optics) by an observer who had no information about the subjects from whom the samples were obtained; the percentage of cells with one or more 'pits' was calculated and taken as a measure of splenic hypofunction. ${ }^{3}$

\section{STATISTICS}

The levels of pitted cells before and during treatment were compared using Wilcoxon's rank sum test for paired data.

\section{Results}

The percentage of pitted cells in 15 coeliacs before and during treatment in shown in the Figure. Basal 


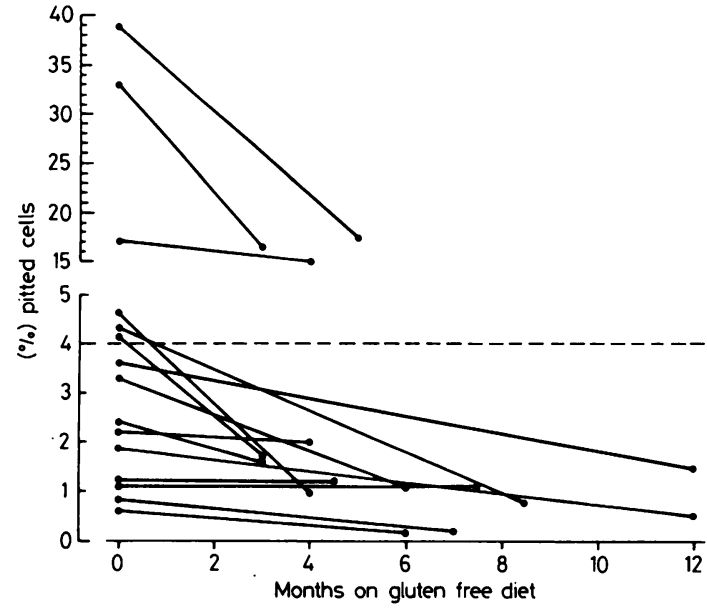

Figure Percentage of pitted cells in 15 coeliac patients before and during a gluten-free diet. The broken line represents upper limit of normal range.

levels of pitted cells decreased significantly $(p<0.005)$ after a gluten-free diet. Before gluten withdrawal six patients out of $15(40 \%)$ showed a percentage of pitted cells higher than the $4 \%$ taken as the upper limit of the normal range. ${ }^{3}$ During a gluten-free diet the levels of pitted cells fell into the normal range in three of the six hyposplenic coeliacs. No correlation was found between the duration in months of a gluten-free diet and the percentage of recovery of splenic function over the basal values $(r=0 \cdot 334, N S)$.

\section{Discussion}

In several diseases complicated by impaired splenic function, such as ulcerative colitis, ${ }^{9}$ systemic lupus erythematosus, ${ }^{10}$ and rheumatoid arthritis, ${ }^{11}$ the severity of splenic hypofunction fluctuates with disease activity. In ulcerative colitis steroid treatment and removal of the diseased colon ${ }^{912}$ may be followed by recovery of splenic function. This is also seen in nephritis and vasculitis after treatment by plasma exchange. ${ }^{13}$ These findings strongly suggest that, in some diseases, the blockade of the splenic component of reticuloendothelial function is reversible.

Coeliac disease is considered to be the most frequent cause of non-surgical hyposplenism, ${ }^{7}$ and if it were known whether or not splenic hypofunction in adult coeliac disease is reversed by gluten withdrawal it might give us a better insight into the mechanisms underlying the onset of this complication. Improvement of splenic hypofunction after gluten withdrawal may be suggested by decreased blood platelet counts in coeliacs on a gluten-free diet compared with untreated patients. ${ }^{14} 15$ We agree, however, that thrombocytosis in adult coeliac disease is due not only to the presence of hyposplenism but also to the activity of the bowel lesions. A serial study of splenic function in adult coeliac disease has been performed by Palmer et $\mathrm{al}^{16}$ using the heat-damaged red cell clearance. Although they do not give any information about how long their patients were on a gluten-free diet, their data show that, in all hyposplenic coeliacs, splenic function improved after gluten withdrawal. More recently, Trewby et al have examined routine blood films from 11 coeliacs after periods on a gluten-free diet ranging from two to 15 years. On the basis of the severity of red cell changes they have shown that hyposplenic features become more prominent with time irrespective of whether or not a strict gluten-free diet is observed. Our results, however, show that after three to 12 months of a gluten-free diet the percentage values of pitted cells were significantly lower compared with the basal ones. In three out of the six patients with splenic hypofunction the levels of pitted cells fell into the normal range, whereas, in the other three, who presented very high levels of pitted cells, a gluten-free diet only partially reversed hyposplenism. Although we cannot exclude that longer periods of treatment could induce total recovery also of severe degrees of splenic hypofunction, the lack of correlation between the duration in months of a gluten-free diet diet and the percentage of recovery of hyposplenism, and the raised incidence of splenic hypofunction in coeliacs on a gluten-free diet $^{2}{ }^{3}$ make this hypothesis less tenable. Therefore, our data are in keeping with the suggestion ${ }^{2}$ that there may be two components to splenic hypofunction in adult coeliac disease: splenic atrophy with irreversible loss of volume, and functional impairment, which may improve with treatment. The total recovery that we have observed in three coeliacs with slight impairment of splenic function suggest that, in these patients, only the functional component was present, whereas the partial recovery observed in the other three is consistent with the presence of both atrophy and impaired function.

Several explanations may be given for the disagreement between our results and those of Trewby and his colleagues. ${ }^{8}$ Their grading of red cell changes - presence of irregular cells, target cells, spherocytes, and Howell-Jolly bodies - does not seem to be suitable for serial studies: spherocytes and target cells are not often encountered in postsplenectomy blood films ${ }^{17}$ and are therefore 
unreliable in detecting mild degrees of splenic hypofunction. As far as Howell-Jolly bodies are concerned. they cannot be considered a quantitative measure of splenic reticuloendothelial dysfunction. ${ }^{1 \times}$ On the contrary. the percentage of pitted cells has been shown to corrclate with. and have the same discriminant power as. the heat-damaged red cell clearance. "which can detect hyposplenism even in patients without Howell-Jolly bodies. ${ }^{19}$ Moreover. the discrepancy between our results and those of Trewby and colleagues." may depend also on the different periods of gluten-free diet that are studied. Trewby ${ }^{\prime} t$ al gave no information about splenic function during the first two years of treatment, while we have followed up our patients only in the earlier stages of gluten withdrawal. It is of interest that in Trewby et al's study ${ }^{x}$ the only patient whose splenic function returned to normal was the only one checked at the end of the second year of diet.

It is possible that the improvement of splenic hypofunction that we have observed may be transient and confined to the earlier periods of gluten withdrawal, but we have nevertheless shown that gluten intake is important in maintaining hyposplenism in adult coeliac disease. We conclude that environmental factors may be as important for splenic hypofunction in adult coeliac disease as the hypothetical genetic determinants previously suggested. ${ }^{x}$

\section{References}

1 Marsh GW. Stewart JS. Splenic function in adult coeliac disease. Br J Haematol 1970; 19: 445-57.

2 Robinson PJ, Bullen AW, Hall R, Brown RC, Baxter $P$, Losowsky MS. Splenic size and function in adult coeliac disease. Br J Radiol 1980; 53: 532-7.

3 Corazza GR, Bullen AW, Hall R, Robinson PJ, Losowsky MS. Simple method of assessing splenic function in coeliac disease. Clin Sci 1981; 60: 109-13.
4 Palmer KR. Barber DC. Sherriff S. Holdsworth CD. Reticuloendothelial function in coeliac disease and ulcerative colitis. Gut 1981: 22: A+19.

5 Baker PG. Verrier Jones R. Peacock DB. Read AE. The immune response to $\emptyset \mathrm{X} 174$ in man. III Evidence for an association between hyposplenism and immunodeficiency in patients with coeliac disease. Gut 1975: 16: $538-42$.

6 Bullen AW. Hall R. Cooke EM. Losowsky MS. Immunity and the hyposplenism of coeliac disease (CD). Gut 1977: 18: A961-2.

7 Bullen AW. Hall R. Gowland G. Rajah S. Losowsky MS. Hyposplenism, adult coeliac disease, and autoimmunity. Gut 1981: 22: 28-33.

8 Trewby PN. Chipping PM. Palmer SJ. Roberts PD. Lewis SM. Stewart JS. Splenic atrophy in adult coeliac disease: is it reversible? Gut 1981: 22: 628-32.

9 Ryan FP. Smart RC. Holdsworth CD. Preston FE. Hyposplenism in inflammatory bowel disease. Gut 1978: 19: 50-5.

10 Frank MM, Hamburger MI, Lawley TJ, Kimberly RP. Plotz PH. Defective reticuloendothealial system Fcreceptor function in systemic lupus erythematosus. $N$ Engl J Med 1979; 300: 518-23.

11 Williams BD, Pussell BA, Lockwood CM, Cotton C. Defective reticuloendothelial system function in rheumatoid arthritis. Lancet 1979; 1: 1311-4.

12 Ardeman S, Bevan G. Hyposplenism and ulcerative colitis. Lancet 1974: 2: 588 .

13 Lockwood CM, Worlledge S, Nicholas A. Cotton C. Peters DK. Reversal of impaired splenic function in patients with nephritis or vasculitis (or both) by plasma exchange. $N$ Engl J Med 1979; 300: 524-30.

14 Nelson EW, Ertan A. Brooks FP, Cerda JJ. Thrombocytosis in patients with celiac sprue. Gastroenterology 1976; 70: 1042-4.

15 Bullen AW, Hall R, Brown RC, Losowsky MS. Mechanisms of thrombocytosis in coeliac disease (CD). Gut 1977: 18: A962.

16 Palmer KR, Sherriff SB, Holdsworth CD. Changing pattern of splenic function in coeliac disease. Gut 1980; 20: A920.

17 Lipson RL, Bayrd ED. Watkins CH. The postsplenectomy blood picture. Am J Clin Pathol 1959; 32: 526-32.

18 Casper JD, Koethe S, Rodey GE, Thatcher LG. A new method for studying splenic reticuloendothelial dysfunction in sickle cell disease patients and its clinical application: a brief report. Blood 1976; 41: 183-8.

19 Pettit JE. The spleen. Clin Haematol 1977; 6: 639-56. 